\title{
Coexistence of an Axillary Arch Muscle (Latissimocondyloideus Muscle) with an Unusual Axillary Artery Branching: Case Report and Review
}

\author{
Coexistencia de un Arco Muscular Axilar (Latisimocondíleo) con un \\ Inusual Ramo de la Arteria Axilar: Reporte de Caso y Revisión \\ Soubhagya, R. Nayak; Latha V. Prabhu; Ashwin, K.; Madhan, Kumar S. J. \& C. Ganesh, Kumar
}

SOUBHAGYA, R. N.; LATHA, V. P.; ASHWIN, K.; MADHAN, K. S. J. \& GANESH, C. K. Coexistence of an axillary arch muscle (latissimocondyloideus muscle) with an unusual axillary artery branching: case report and review. Int. J. Morphol., 24(2):147-150, 2006.

SUMMARY: The axilla is a relatively small pyramidal compartment between the thoracic wall and the arm, which contains muscles and vital neurovascular bundles. They are important for their clinical and morphological reasons. We report an anomalous latissimocondyloideus muscle and a rare variant of the axillary artery, which lies beneath the anomalous muscle. The anomaly is one of its kind. The morphology and the clinical significance of the muscle have been reviewed.

KEY WORDS: Axillary arch; Latissimocondyloideus muscle; Axillary artery; Variation; Morphology.

\section{INTRODUCTION}

Anatomical variations of axillary region are well documented but the presence of co-existence of double variant in the same area is very rare. Primarily, the axilla contains the diverging elements derived from the brachial plexus and axillary vessels (Hollinshead, 1958). Occasional presence of an anomalous muscle i.e. axillary arch muscle and the relative closeness of vital structures are of importance to the surgeons and also for academic purposes. The third part of the axillary artery occasionally covered by a muscular slip is always present in early fetal life, but usually atrophies later. In rare cases axillary arch muscles may persist and may be clinically important (Ramsay, 1812). When the axillary arch originates from the tendon oflatissimus dorsi and insert to the brachial and antibrachial fascia, to the humerus, to the lateral epicondyle and olecranon, or to the long head of triceps, it is often called latissimocondyloideus muscle (Bergman, 1988). In case of aneuploidy (trisomy 18) the latissimocondyloideus muscle, is found along with other supernumerary muscles, a regular feature found in monkeys and great apes. It is also believed that these supernumerary muscles may be "atavistic" structures (Aziz, 1979, 1981). The axillary arch muscles occur in about $7 \%$ and may be multiple (Kasai \& Chilba, 1977). The axillary artery can conveniently be considered as the central axis of the axilla, since the veins of the axilla tend to follow the artery and its branches and the brachial plexus is arranged around the artery (Hollinshead).

The axillary artery is traditionally described as giving off six branches, but the number arising independently from it is subject to considerable variations. Two or more of its usual branches may arise by a common trunk or a branch of the named artery may arise separately (Hollinshead). De Garis and Swartley (1928) described 23 different types of axillary artery. They said that there is a greater tendency in the Negroes than in Whites towards clumping of the branches, with two or more arising in common, and that there is also a greater variety of patterns in the Negroes than in the Whites. Trottler and her associates found a sex difference in the branching pattern (Trotter et al., 1930). The seventh cervical segmental artery gives rise to axillary artery and any abnormality during development results in the unusual branching pattern (Wollard, 1922). 
The co-existence of a latissimocondyloideus muscle and an unusual axillary artery branching in same extremity is very rare and never reported before.

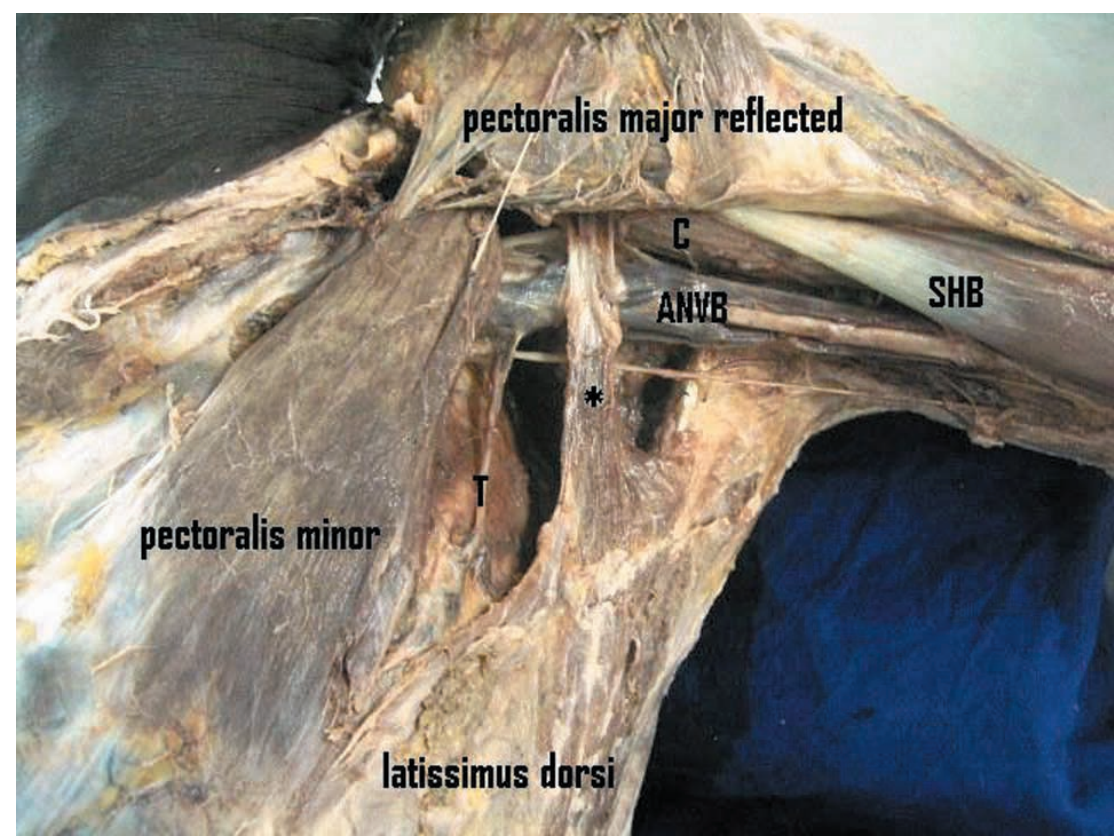

Fig. 1. Anterior view of the left axillary region. C- coracobrachialis muscle, ANVB- axillary neuro vascular bundle, SHB- short head of biceps.

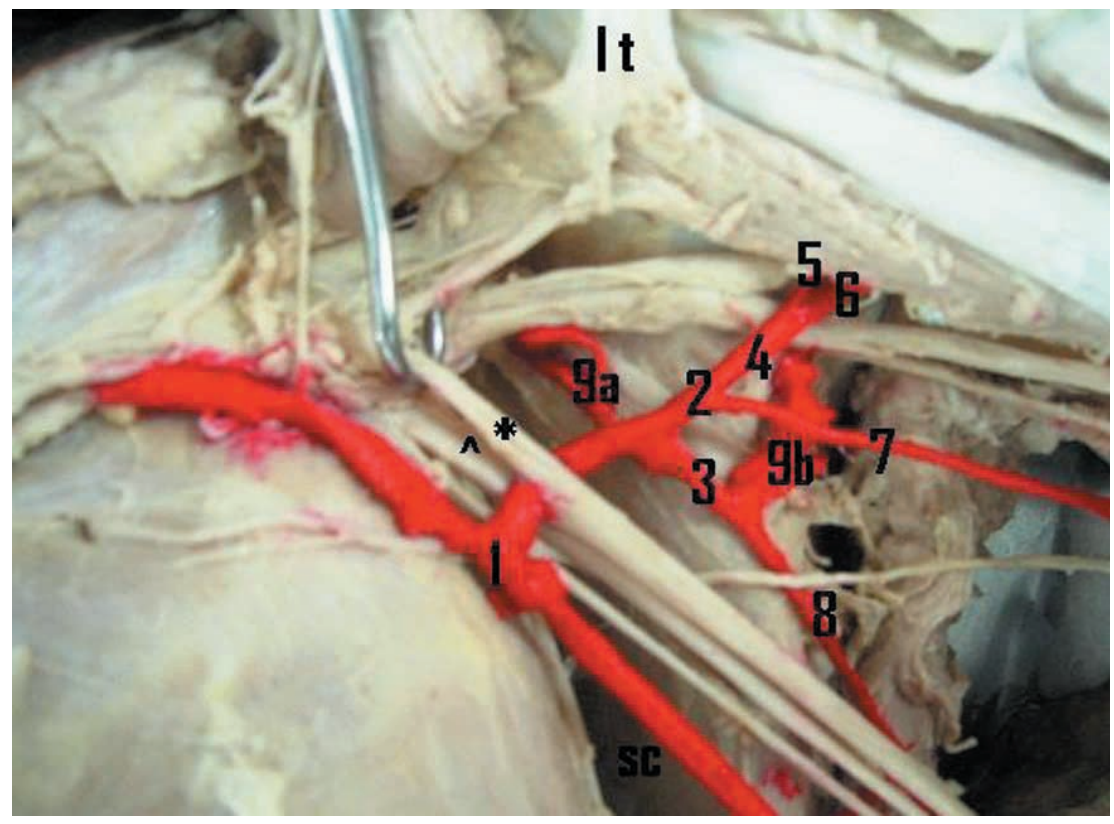

Fig. 2. Anterior view of the left axillary region after exposure of anomalous muscle. Ltlatissimocondyloideus muscle tendon. 1. Third part of axillary artery; 2. Lateral branch from the main trunk; 3 . Medial branch from the main trunk; 4. Common humeral circumflex artery; 5. Anterior circumflex humeral artery; 6. Posterior circumflex humeral artery; 7. Superior ulnar collateral artey; 8 . Thoracodorsal artery; 9a. Medial circumflex scapular artery; 9b. Lateral circumflex humeral arteries; * Lateral root of median nerve; ^ Medial root of median nerve; SC. Scapula.

\section{CASE REPORT}

During routine dissection of the left axillary region of an adult male cadaver, we encountered a double anatomical variant in the same region. An anomalous axillary arch muscle (latissimocondyloideus muscle) from the upper part of the tendon of latissimus dorsi, $7.5 \mathrm{~cm}$ before its insertion and ran below the pectoralis major, crossed over the axillary vessels and nerves of the brachial plexus to be inserted into the fascia covering the common tendon of short head of biceps brachii and coracobrachialis. The length of the anomalous latissimocondyloideus muscle was $12.5 \mathrm{cms}$; the breadth of the muscle at its origin was $4.6 \mathrm{cms}$ and $1.7 \mathrm{cms}$ at its insertion. The muscle was running in the mid-axillary region.

During the exposure of the anomalous muscle, we found that the third part of the axillary artery, beneath the latissimocondyloideus muscle was having anomalous branching pattern. The third part of the axillary artery gave only one main trunk $(2.5 \mathrm{cms})$, in between the two roots of the median nerve, the artery being compressed at this region. The main arterial trunk then divided into two main branches, lateral and medial. The lateral branch gave (I) common humeral circumflex artery, which divided into anterior and posterior circumflex humeral arteries, the latter continued as the profunda brachii artery in the radial groove, along with the radial nerve (II). Superior ulnar collateral artery that ran along the medial side of the arm up to elbow joint. The medial branch was the subscapular artery, which in turn gave three circumflex scapular arteries; one medial and two lateral to the scapular border, the artery then continued as thoracodorsal artery, with the thoracodorsal nerve and supplied the medial wall of axilla and latissimus dorsi muscle. 
Coexistence of an axillary arch muscle (Latissimocondyloideus muscle) with an unusual axillary artery branching: case report and review. Int. J. Morphol., 24(2):147-150, 2006.

\section{DISCUSSION}

The axillary arch muscle in its various forms, including latissimocondyloideus muscle is often overlooked. When an axillary arch muscle is encountered during axillary lymphadenectomy, the lymph node posterior and lateral to the arch should be excised (Petrasek et al., 1997) The muscular arch when present causes difficulties in staging lymph nodes, axillary surgery, thoracic outlet syndrome, shoulder instability or cosmetic problems (Ucerler et al.,2005). In this case, the axillary arch muscle tendon crossed the axillary artery, just above the spot usually selected for the application of a ligature, and may mislead the surgeon during the operation (Gray, 1918; del Sol \& Olave, 2005). The accessory muscle present in the axillary area can be a reason of an axillary mass and can exert pressure on the neighboring neurovascular bundle or lymph routes, thus exposing a wide range of symptoms (Turgut et al., 2005). The mid axillary position of tendon of the latissimocondyloideus muscle should be kept in mind while draining the axillary abscess. The variable origin of the circumflex humeral, subscapular and profunda brachii arteries are not only of clinical importance to orthopaedic and reconstructive surgeons, but also have significant medico-legal implications (Pandey et al., 2004).

The abnormal arterial trunk may get compressed as it passes between the two roots of the median nerve. According to Telford \& Mottershead (1948), certain cases of obliteration of the radial pulse with depression of the shoulder, may be due to axillary artery passing between the two roots of the median nerve.

We conclude that the latissimocondyloideus muscle and axillary artey has immense clinical and morphological significance.

SOUBHAGYA, R. N.; LATHA, V. P.; ASHWIN, K.; MADHAN, K. S. J. \& GANESH, C. K. Coexistencia de un arco muscular axilar (latisimocondíleo) con un inusual ramo de la arteria axilar: Reporte de caso y revisión. Int. J. Morphol., 24(2):147-150, 2006.

RESUMEN: La axila es un compartimiento piramidal relativamente pequeño, localizado entre la pared torácica y el brazo, que contiene músculos y estructuras neurovasculares. Estas estructuras son importantes desde los puntos de vista clínico y morfológico. En este artículo reportamos la presencia de una variación del músculo latisimocondíleo y de la arteria axilar, la cual se encuentra debajo del músculo mencionado. La variación es única en su tipo. La morfología y el significado clínico del músculo son discutidos.

PALABRAS CLAVE: Arco axilar: Músculo latisimocondíleo; Arteria axilar; Variación anatómica; Morfología.

\section{REFERENCES}

Aziz, M. A. Muscular and other abnormalities in a case of Edward's syndrome (18-Trisomy). Teratology, 20(2):303-12, 1979.

Aziz, M. A. Possible "atavistic" structures in human aneuploids. Am. J. Phys. Anthropol., 347-53, 1981.

Bergman, R. A.; Thompson, S. A.; Afifi, A. K. \& Saadeh, F. A. Compendium of Human Anatomic variation: Catalog, Atlas and World Literature. Baltimore, Urban \& Schwanzenberg, 1988.

De Garis, C. F. \& Swartley, W. B. The axillary artery in White and Negro stocks. Am. J. Anat., 41:353, 1928.

Del Sol, M. \& Olave, E. Elevator muscle of the tendon of latissimus dorsi muscle. Clin. Anat., 18(2): 112-4, 2005.
Gray, H. Anatomy of Human Body. Philadelphia: Lea \& Febiger, 1918. pp. 434.

Hollinshead, W. H. Anatomy for surgeons in general surgery of the upper limb. The back and limbs. New York, A Heber Harper Book, 1958. V. 3. pp.290-300.

Kasai, T. \& Chilba, S. True nature of the muscular arch of the axilla and its nerve supply. Kaibogakuzasshi., 25:65769, 1977.

Pandey, S. K.; Gangopadhyay, A. N.; Tripathi, S. K. \& Shukla, V. K. Anatomical variations in terminations of the axillary artery and its clinical implications. Med. Sci. law., 44(1): 61-6, 2004.

Petrasek, A. J.; Semple, J. L. \& Mccready, D. R. The 
surgical and oncologic significance of the axillary arch during axillary lymphadenectomy. Can. J. Surg., 40(1):44-7, 1997.

Ramsay, A. An account of unusual conformation of some muscles and vessels. Edinburgh. Med. Surg. J., 8:281283,1812 .

Telford, E. D. \& Mottershead, S. Pressure at the cervico brachial junction: An operative and Anatomical study. J. Bone \& Joint Surg., 30-B:249, 1948.

Trottler, M.; Henderson, J. L.; Gass, H. ; Brua, R. S; Weisman, S.; Agrecs, H.; Curtis, G. H \& West brooks, E. R. The origins of branches of the axillary artery in whites and in American Negroes. Anat. Rec., 46:133, 1930.

Turgut, H. B.; Peker, T.; Gulekon, N.; Anil, A. \& Karakose, M. Axillopectoral muscle (Langer's muscle). Clin.Anat., 18(3):220-3, 2005.

Ucerler, H.; I. Kiz, Z. A. \& Pinan, Y. Clinical importance of the muscular arch of the axilla / axillopectoral muscle, Langer's axillary arh. Acta. Chir. Belg., 105 (3): 326-8, 2005.

Wollard, H. H. The development of the principal arterial stems in the forelimb of the pig. Contrib. Embryol., 14:139, 1922.
Correspondence to: Dr. Soubhagya R. Nayak Department of Anatomy Centre for Basic Sciences Kasturba Medical College, Bejai Mangalore, 575004, Karnataka - IN $\mathcal{N} I \mathcal{A}$

Phone: +918242211746

Fax: $\quad+918242421283$

Email: ranjan6hatana@gmail.com.

Received: 25-11-2005

Accepted: 01-02-2006 